\title{
Cladistic analysis and description of a new species of the Brazilian genus Atlantodesmus Hoffman, 2000 (Diplopoda: Polydesmida: Chelodesmidae)
}

\author{
Rodrigo Salvador BOUZAN ${ }^{1, *}$, Luiz Felipe Moretti INIESTA ${ }^{2}$ \& \\ Antonio Domingos BRESCOVIT ${ }^{3}$ \\ 1,2 Pós-graduação em Zoologia, Instituto de Biociências, Universidade de São Paulo, São Paulo, Brasil. \\ ${ }^{1,2,3}$ Laboratório Especial de Coleções Zoológicas, Instituto Butantan, Avenida Vital Brasil, 1500, \\ 05503-090, São Paulo, Brasil. \\ *Corresponding author: rodrigobouzan@outlook.com \\ 2Email: luiz-moretti@hotmail.com \\ ${ }^{3}$ Email: adbresc@terra.com.br \\ ${ }^{1}$ urn:1sid:zoobank.org:author:14A15A7F-730F-4D41-BDAC-D53514FAB85D \\ ${ }^{2}$ urn:1sid:zoobank.org:author:DEEF048E-97FB-4CCD-875F-5FA6184CA8AB \\ ${ }^{3}$ urn:1sid:zoobank.org:author:D5B81D79-AFAE-47B1-8A6E-DAB448A24BCC
}

\begin{abstract}
A cladistic analysis of the genus Atlantodesmus Hoffman, 2000 is presented. With a total of 11 taxa and 30 morphological characters, and under implied weighting $(\mathrm{k}=3)$, two equally most parsimonious trees (length $=58$ steps; total fit $=23.150 ; \mathrm{CI}=0.64 ; \mathrm{RI}=0.64$ ) recovered the monophyly of the genus. The resulting synapomorphies are: absence of a ventral projection on the post-gonopodal sternites; presence of folds on the dorsal edge of the prefemoral region of the gonopod; and one homoplastic transformation: presence of a cingulum. In addition, Atlantodesmus sierwaldae sp. nov. is described from the state of Minas Gerais, in the Brazilian Cerrado, and a key to the males of the genus is provided.
\end{abstract}

Keywords. Brazil, Neotropical region, Brazilian Cerrado, Chelodesminae, taxonomy.

Bouzan R.S., Iniesta L.F.M. \& Brescovit A.D. 2019. Cladistic analysis and description of a new species of the Brazilian genus Atlantodesmus Hoffman, 2000 (Diplopoda: Polydesmida: Chelodesmidae). European Journal of Taxonomy 538: 1-17. https://doi.org/10.5852/ejt.2019.538

\section{Introduction}

The Chelodesmidae Cook, 1895 is the second largest family in the class Diplopoda de Blainville, 1844, with almost 800 described species (Hoffman 1980). The family is divided into two subfamilies: Chelodesminae Cook, 1895, composed of 19 tribes distributed in the Neotropical region, and Prepodesminae Cook, 1896, with only one tribe from Africa and disjuncts records from Spain (Hoffman 1980). 
In the Chelodesminae, the genus Atlantodesmus Hoffman, 2000 contains species widely distributed in the Atlantic forest of Brazil (Hoffman 2000; Bouzan et al. 2017). The genus is not assigned to any tribe, though Hoffman (2000) suggested a close relationship with members of the genus Arthrosolaenomeris Schubart, 1943 in the tribe Arthrosolaenomeridini Hoffman, 1976, due to the presence of a cingulum on the gonopod and a supposedly similar geographic distribution. Recently, Atlantodesmus was revised and considered as a senior synonym of Iemanja Hoffman, 2000 (Bouzan et al. 2017), and is currently composed of the species A. eimeri (Attems, 1898), A. itapurensis (Schubart, 1943), A. pickeli (Schubart, 1946), A. pintoi (Schubart, 1946) and A. teresa (Hoffman, 2000).

In this study, a morphology-based cladistic analysis is performed to test the monophyly of Atlantodesmus. In addition, Atlantodesmus sierwaldae sp. nov. from the state of Minas Gerais, Brazil, is described based on several differences in the morphology of the gonopod, and an updated key to the males of the genus is provided.

\section{Material and methods}

The material examined is deposited in the following institutions indicated below (curators in parentheses). Photographs were taken with a Leica DFC 500 digital camera mounted on a Leica MZ16A stereo microscope. Focus-staked images were composed with Leica Application Suite version 2.5.0. For the gonopod terminology we follow Pena-Barbosa et al. (2013), Koch (2015) for the cyphopod terminology, and Attems (1898) and Brölemann (1900) for other somatic characters.

\section{Repositories}

CZUFMT MYR = Coleção Zoológica da Universidade Federal do Mato Grosso, Cuiabá, Mato Grosso, Brazil (A. Chagas-Jr)

IBSP $\quad=\quad$ Instituto Butantan, São Paulo, Brazil (A.D. Brescovit)

MZSP $\quad=$ Museu de Zoologia, Universidade de São Paulo, Brazil (R. Pinto da Rocha)

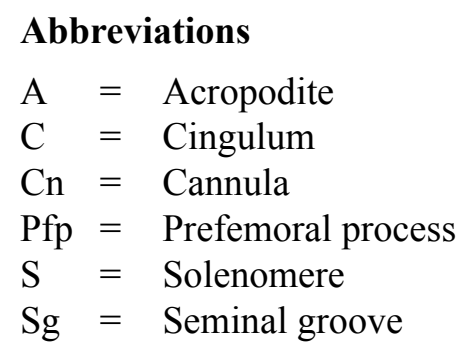

\section{Cladistic analysis}

All recognized species in the genus Atlantodesmus were included in the cladistic analyses. Members of the tribes Strongylomorphini: Brasilodesmus paulistus paulistus (Brölemann, 1902), Macrocoxodesmini: Macrocoxodesmus marcusi Schubart, 1947, and Arthrosolaenomeridini: Arthrosolaenomeris pantalanensis Schubart, 1943 were included as outgroups, as well as two species not assigned to any tribe (Leiodesmus sp. and Plectrogonodesmus gounellei (Brölemann, 1902)), hypothesized to be closely related to Atlantodesmus, according to Hoffman (2000) and Bouzan et al. $(2017,2019)$.

The character construction was based on established procedures for morphological cladistic analyses, such as topological correspondence between the structures, similarity, and hierarchy and independence between characters and states (Rieppel \& Kearney 2002). Contingent character construction was employed in some cases (Strong \& Lipscomb 1999), due to the relationship concerning the presence/absence of structures (neomorphic feature) and their possible shapes (transformational) (Sereno 2007). The character matrix (Tables 1-2) was constructed using the program ASADO ver. 1.89 (Nixon 2004). All characters were 
Table 1. Morphological matrix for the cladistic analysis of the genus Atlantodesmus Hoffman, 2000. $-=$ inapplicable characters; ? = unobserved characters. All characters were treated as nonadditive.

\begin{tabular}{|c|c|c|c|c|c|c|c|c|c|c|c|c|c|c|c|c|c|c|c|c|c|c|c|c|c|c|c|c|c|c|}
\hline \multirow[t]{2}{*}{ Terminals } & \multicolumn{30}{|c|}{ Characters } \\
\hline & $\mathbf{0}$ & $\mathbf{0}$ & $\mathbf{0}$ & $\mathbf{0}$ & $\mathbf{0}$ & $\mathbf{0}$ & $\mathbf{0}$ & $\mathbf{0}$ & $\mathbf{0}$ & 1 & 1 & 1 & 1 & 1 & 1 & 1 & 1 & 1 & 1 & 2 & 2 & 2 & 2 & 2 & 2 & 2 & 2 & 2 & 2 & \\
\hline & 1 & 2 & 3 & 4 & 5 & 6 & 7 & 8 & 9 & $\mathbf{0}$ & 1 & 2 & 3 & 4 & 5 & 6 & 7 & 8 & 9 & $\mathbf{0}$ & 1 & 2 & 3 & 4 & 5 & 6 & 7 & 8 & 9 & 0 \\
\hline Brasilodesmus paulistus & 1 & 0 & 0 & 0 & 1 & 0 & 0 & 0 & 1 & 1 & 0 & 0 & 0 & 1 & 1 & 0 & 0 & 0 & 0 & 1 & 0 & - & - & 0 & 0 & 0 & 0 & - & 0 & 0 \\
\hline Macrocoxodesmus marcusi & 1 & 0 & 0 & 0 & 1 & 1 & 1 & 1 & 1 & 1 & 1 & 1 & 1 & 2 & 0 & 1 & 2 & 0 & 1 & 0 & 0 & - & - & 0 & 0 & 0 & 1 & 2 & 1 & 0 \\
\hline Plectrogonodesmus gounellei & 0 & - & 0 & - & 1 & 1 & 1 & 0 & - & 1 & - & 1 & 1 & 1 & 0 & 1 & 2 & 0 & 0 & 0 & 0 & - & - & 0 & 0 & 0 & 1 & 0 & 1 & 0 \\
\hline Leiodesmus sp. & 1 & 1 & 0 & 0 & 1 & 1 & 1 & 1 & 1 & 0 & 1 & 1 & 1 & 2 & 0 & 1 & 1 & 0 & 0 & 0 & 0 & - & - & 0 & 0 & 0 & 0 & - & $?$ & ? \\
\hline Arthrosolaenomeris pantalanensis & 1 & 1 & 0 & 0 & 1 & 1 & 1 & 1 & 1 & 0 & 1 & 1 & 0 & 1 & 0 & 1 & 1 & 0 & 0 & 1 & 1 & 1 & 0 & 0 & 0 & 0 & 0 & - & 1 & 0 \\
\hline Atlantodesmus teresa & 0 & - & 1 & 1 & 0 & 0 & 0 & 0 & 0 & 1 & 2 & 0 & 1 & 1 & 1 & 1 & 0 & 1 & 1 & 0 & 1 & 0 & 2 & 0 & 0 & 0 & 1 & 1 & 1 & 0 \\
\hline Atlantodesmus eimeri & 1 & 1 & 0 & 1 & 1 & 0 & 0 & 0 & 0 & 1 & 2 & 0 & 1 & 1 & 0 & 1 & 0 & 1 & 1 & 0 & 1 & 1 & 1 & 0 & 1 & 1 & 1 & 1 & 1 & 0 \\
\hline Atlantodesmus pickeli & 1 & 0 & 0 & - & 0 & 0 & 0 & 0 & 0 & 1 & 2 & 0 & 1 & 2 & 0 & 0 & 0 & 0 & 1 & 0 & 1 & 0 & 2 & 0 & 1 & 0 & 1 & 1 & - & . \\
\hline Atlantodesmus pintoi & 1 & 2 & 0 & 0 & 0 & 0 & 0 & 0 & 0 & 1 & 2 & 0 & 1 & 0 & 0 & 0 & 0 & 1 & 1 & 0 & 1 & 0 & 2 & 1 & 1 & 0 & 1 & 1 & 2 & 1 \\
\hline Atlantodesmus itapurensis & 0 & - & 0 & 0 & 1 & 0 & 0 & 0 & 0 & 1 & 0 & 0 & 1 & 1 & 0 & 1 & 0 & 1 & 0 & 0 & 1 & 1 & 2 & 1 & 0 & 0 & 1 & 1 & 2 & 1 \\
\hline Atlantodesmus sierwaldae sp. nov. & 1 & 1 & 0 & 1 & 0 & 0 & 0 & 0 & 0 & 1 & 2 & 0 & 1 & 1 & 0 & 1 & 0 & 1 & 0 & 0 & 1 & 1 & 1 & 1 & 0 & 1 & 1 & 1 & - & - \\
\hline
\end{tabular}


Table 2 (continued next page). List of character and character states used in the cladistic analysis of the genus Atlantodesmus Hoffman, 2000.

\# Character

Character state

(1) Coloration of the body rings (Pena-Barbosa et al. 2013, character \#6): 0 - Uniform; 1 - Not uniform (Fig. 3).

(2) Patches of color on the paranota: 0 - On lateral margin (Fig. 4A); 1 - Extended to posterior edge (Fig. 4C); 2 - On central area (Fig. 4B).

(3) Tegument of the body rings: 0 - Smooth (Fig. 4A-C); 1 - Granular (Fig. 4D).

(4) Edge of the lateral projection on the seventh sternite: 0 - Smooth (Fig. 4A); 1 - Serrated (Fig. 4B).

(5) Ventral projection on the fourth sternite: 0 - Absent; 1 - Present (Fig. 5C).

(6) Ventral projection on the fifth sternite: 0 - Absent; 1 - Present (Fig. 5D).

(7) Ventral projection on the sixth sternite (Pena-Barbosa et al., 2013, character \#9): 0 - Absent; 1 - Present.

(8) Ventral projection on the seventh sternite (Pena-Barbosa et al., 2013, character \#10): 0 - Absent; 1 - Present.

(9) Ventral projection on the sternites just after the gonopods (Pena-Barbosa et al., 2013, character \#18): 0 -Absent; 1 - Present.

(10) Shape of the posterior edge of the paranota (Pena-Barbosa et al., 2013, character \#21): 0 - Rounded (Fig. 5E); 1 -Acuminate (Fig. 5F).

(11) Paranota alignment in oral view (Pena-Barbosa et al., 2013, character \#13): 0 - Straigth; 1 - Curved ventrad; 2 - Curved dorsad.

(12) Dorsal lobe on the prefemur of the fifth leg (Pena-Barbosa et al., 2013, character \#16): 0-Absent; 1 - Present.

(13) Folds on the aperture of the gonopod (Pena-Barbosa et al., 2013, character \#20): 0 - Absent; 1 - Present (Fig. 6A).

(14) Posterior edge of gonopod aperture (Pena-Barbosa et al., 2013, character \#23): 0 - Not extended to coxae of the legs; 1 - Extended up to half of the coxae; 2 - Exceeding the coxae.

(15) Coxal apophysis (Pena-Barbosa et al., 2013, character \#27): 0 - Absent; 1 - Present.

(16) Setae on the gonocoxae: 0 - Two setae; 1 - A row of setae.

(17) Shape of the projection on the gonocoxae: 0 - Oval; 1 - Subtriangular; 2 - Digitiform.

(18) Folds on dorsal edge of the prefemoral region: 0 - Absent; 1 - Present (Fig. 6B).

(19) Prefemoral process: 0 - Smooth (Fig. 6C); 1 - Serrated (Fig. 6D).

(20) Projection on prefemoral process (Pena-Barbosa et al., 2013, character \#47): 0 - Absent; 1 - Present. 
Table 2 (continued). List of character and character states used in the cladistic analysis of the genus Atlantodesmus Hoffman, 2000.

\section{\# Character}

\section{Character state}

(21) Cingulum: 0-Absent; 1 - Present.

(22) Shape of the cingulum: 0 - Reduced; 1 - Well-developed (Fig. 2E-F).

(23) Cingulum position: 0 - Medial ; 1 - Proximal; 2 - Submedial.

(24) Acropodite incision in mesal view: 0 - Absent; 1 - Present.

(25) Lobe on the basis of the solenomere: 0 - Absent; 1 - Present.

(26) Lateral membrane of the process of the acropodite: 0 -Absent; 1 - Present.

(27) Solenomere branching: 0 - Absent; 1 - Present.

(28) Position of the solenomere branching: 0-Apical; 1 - Medial; 2 - Proximal.

(29) Shape of the vulva in ventral view (Pena-Barbosa et al., 2013, character \#46): 0 - Circular; 1 - Oval; 2 - Triangular.

(30) Shape of the apex of the vulva: 0 - Rounded; 1 - Triangular.

treated as nonadditive. The search for the most parsimonious cladograms were carried out heuristically in TNT ver. 1.5 (Goloboff \& Catalano 2016). The searches of the trees were conducted under implied weights of the characters (Goloboff 1993; Goloboff et al. 2008a, 2017) and with different values for the constant $\mathrm{k}(1-7)$. The analysis was conducted following the Traditional search, with 1000 replications and 100 trees held per replicate. Concerning the different topologies for different values of $k$, the tree topology that shared the highest number of nodes with the other trees was considered the most stable, and thus, used for the our discussion. The measurement of the sharing was made by subtree prune and regraft [SPR-distances] (Goloboff et al. 2008b). Branch support was calculated through relative Bremer support (Bremer 1994; Goloboff \& Farris 2001) and by Symmetric Resampling approach (Goloboff et al. 2003) under implied weights of the characters, using the Traditional search with 700 replications and 2000 resampled matrices. The strict consensus of the two most parsimonious trees is presented in Fig. 1 with only unambiguous changes. The list of terminal taxa scored for the cladistic analysis is presented in Appendix 1.

\section{Results}

\section{Taxonomy}

Order Polydesmida Pocock, 1887

Suborder Leptodesmidea Brölemann, 1916

Family Chelodesmidae Cook, 1895

Subfamily Chelodesminae Cook, 1895

Genus Atlantodesmus Hoffman, 2000

Atlantodesmus Hoffman, 2000: 102. Type species: Leptodesmus eimeri Attems, 1898, by original designation. 
Iemanja Hoffman, 2000: 106. Type species: I. teresa Hoffman, 2000, by original designation. Synonymized by Bouzan et al. 2017: 271.

\section{Diagnosis}

Modified from Bouzan et al. (2017): males of Atlantodesmus differ from other chelodesmid genera by the combination of the following characters: absence of ventral projections on the sternites (except A. itapurensis and A. teresa, which have a pair of projections on the fourth sternite; Fig. 5C); presence of folds on the dorsal edge of the prefemoral region of the gonopod (Fig. 6B), except A. pickeli; presence of a cingulum (Fig. 2E-F); acropodite branching, forming a long, thin, falciform solenomere, and a large acropodite process with a broadened apical region overreaching the tip of the solenomere (Fig. $2 \mathrm{C}-\mathrm{F}$ ).

\section{Distribution}

Occurring in the Atlantic rain forest (states of Paraná, Santa Catarina, São Paulo, Minas Gerais, Espírito Santo and Bahia) and in the Cerrado (states of São Paulo, Mato Grosso do Sul and Minas Gerais) areas of Brazil. See map in Bouzan et al. (2017).

\section{Composition}

Six species: Atlantodesmus eimeri (Attems, 1898), A. itapurensis (Schubart, 1943), A. pickeli (Schubart, 1946), A. pintoi (Schubart, 1946), A. teresa (Hoffman, 2000) and A. sierwaldae sp. nov.

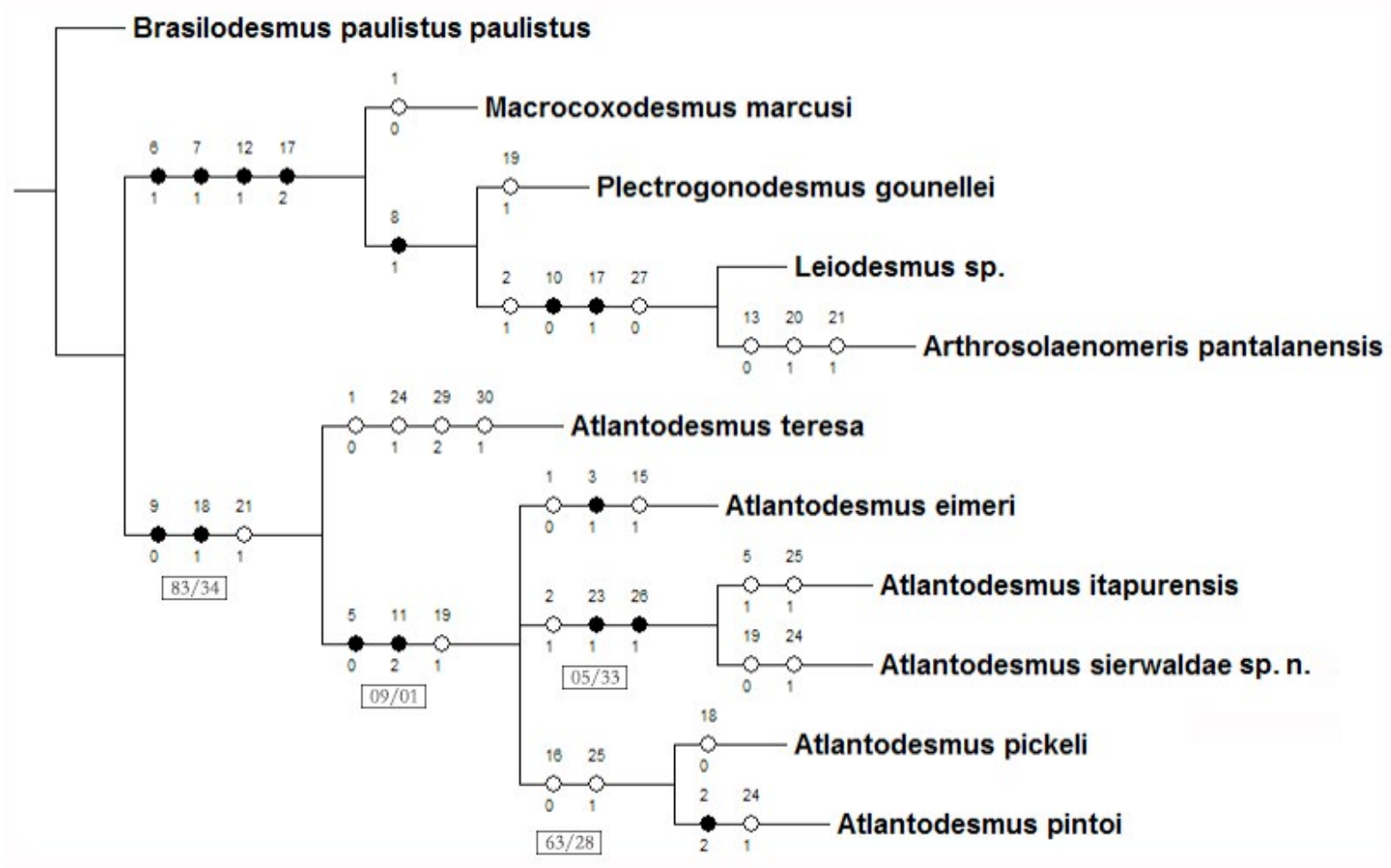

Fig. 1. Strict consensus of the two most parsimonious trees obtained with implied weighting of the characters $(\mathrm{k}=3)($ length $=58$ steps; total fit $=23.150 ; \mathrm{CI}=0.64 ; \mathrm{RI}=0.64)$. Black circles correspond to unique transformations and white circles to homoplastic transformations. Values below branches refer to the GC values (Symmetric Resampling) and relative Bremer support. Only unambiguous changes are shown in this topology. 


\section{Key to the males of Atlantodesmus}

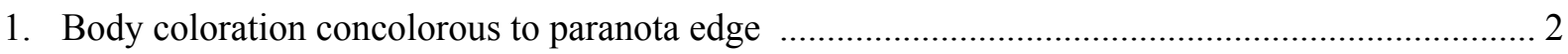

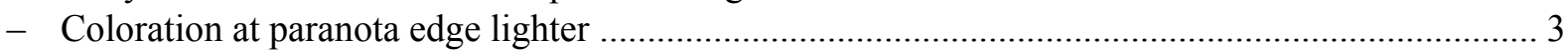

2. Tubercles present on dorsal surface of metazonites

A. eimeri (Attems, 1898)

- Tubercles absent on dorsal surface of metazonites

3. Median stripe on metazonite present

A. pintoi (Schubart, 1946)

- Median stripe on metazonite absent

4. Prefemoral process serrated distally

- Prefemoral process unserrated distally A. sierwaldae sp. nov.

5. Prefemoral process densely serrated distally A. pickeli (Schubart, 1946)

- Prefemoral process slightly serrated distally A. itapurensis (Schubart, 1943)

Atlantodesmus sierwaldae sp. nov. urn:lsid:zoobank.org:act:499BF939-82E7-4191-AD2D-5E3B4240FF1E

Figs $2-4 \mathrm{C}$

\section{Diagnosis}

Males differ from all other species of the genus by the following features: paranota and posterior border of the metaterga whitish (Fig. 2A); tip of acropodite hood-shaped, covering the solenomere only in mesal view (Fig. 2C, E); prefemoral process of the gonopod without serrated margin (Fig. 2E-F).

\section{Etymology}

The specific epithet is a patronym in honor of Dr. Petra Sierwald, for her friendship and outstanding contributions to our knowledge concerning millipedes.

\section{Material examined}

\section{Holotype}

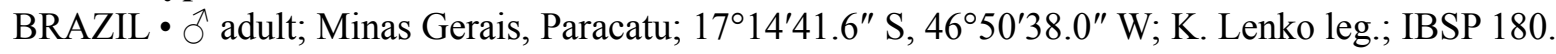

\section{Description}

\section{Male (holotype)}

Measurements. Total length: $47.6 \mathrm{~mm}$. Width (body ring 5): $7.2 \mathrm{~mm}$. Collum length $1.3 \mathrm{~mm}$, width $5.5 \mathrm{~mm}$. Antennomeres in $\mathrm{mm}(1-7): 0.8 ; 1.5 ; 1.6 ; 1.4 ; 1.3 ; 1.3 ; 0.4$. Podomeres in mm (1-6): $0.9 ; 0.9$; $2.0 ; 1.1 ; 1.1 ; 1.5$. Tarsal claw: 0.3 . Gonopod aperture: $1.1 \mathrm{~mm}$ length, $1.9 \mathrm{~mm}$ width. Telson $1.2 \mathrm{~mm}$.

Coloration (in 70\% ethanol). Head light brown with whitish labral region (Fig. 2A). Antennae whitishyellow. Body brown; paranota and posterior margin of metaterga whitish.

BODY RINGS. Integument slightly rough; alignment of paranota curved slightly dorsad; anterior corners rounded, posterior edges acutely produced; ozopores and peritremata situated on the posterior edge of paranota (Fig. 4C). Sterna without modifications.

LEGS. Whitish yellow and without modifications, with thin and slightly elongated setae. Gonopod aperture transversely oval; posterior edge excavated and with folds. Telson light brown with whitish apex (Fig. 2B); hypocroct triangular, with two setae. 
Gonopods (Fig. 2C-F). Gonopod: length $2.22 \mathrm{~mm}$, width $1.79 \mathrm{~mm}$. Coxae: length $0.61 \mathrm{~mm}$, width $0.93 \mathrm{~mm}$. Telopodite: length $1.99 \mathrm{~mm}$, width $0.61 \mathrm{~mm}$. Coxae equivalent to about half the length of telopodite and prominently rounded in ectal view (Figs 2F, 3C); with two or three long setae on distal dorsal side and with two or four short setae above cannula; without a spiniform process. Cannula hookshaped ( $\mathrm{Cn}$; Figs 2C, 3A). Prefemoral region $1 / 3$ the size of telopodite; dorsal side with folds. Prefemoral process a long and broad, smooth blade, with the terminal portion expanded, acuminate at apex (PfP; Figs $2 \mathrm{C}-\mathrm{F}, 3)$. Conspicuous cingulum present below bases of solenomere and acropodite $(C$; Figs $2 \mathrm{E}-\mathrm{F}$, $3)$. Solenomere long and falciform, tapering to acuminate tip; carrying the seminal groove to apical point $(S$; Figs 2E-F, 3B-C). Acropodite long, obscuring solenomere in most of its length in ectal view;
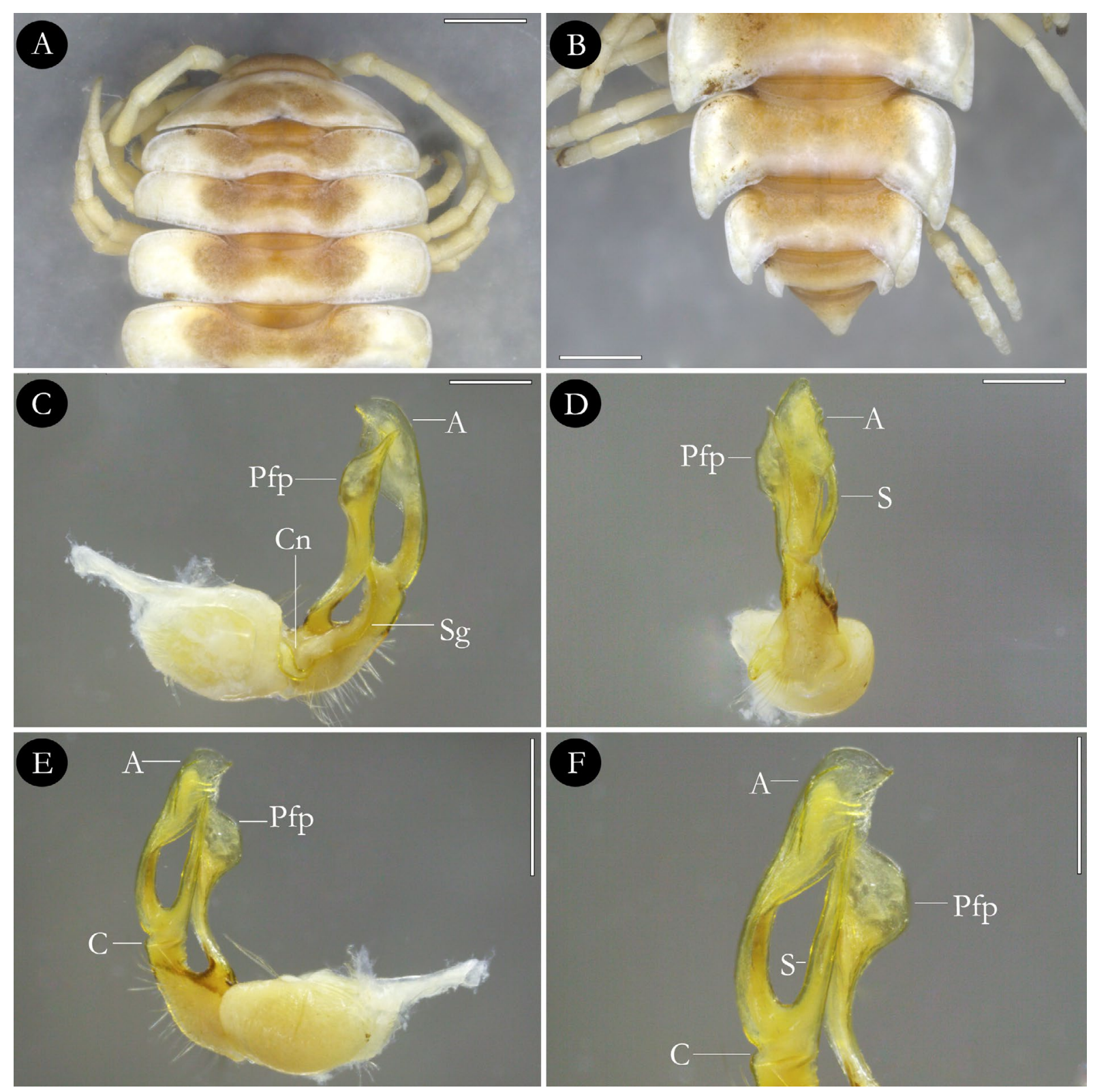

Fig. 2. Atlantodesmus sierwaldae sp. nov., holotype, ठิ (IBSP 180). A. Anterior region in dorsal view. B. Posterior region in dorsal view. C-F. Left gonopod. C. Mesal view. D. Ventral view. E. Ectal view. F. Detail of the distal portion in ectal view. Scale bars: A-B $=2 \mathrm{~mm} ; \mathrm{C}-\mathrm{D}=250 \mu \mathrm{m}$. $\mathrm{E}-\mathrm{F}=500 \mu \mathrm{m}$. 
overreaching the solenomere; hood-shaped. Prefemoral process covering the solenomere in most of its length in mesal view. Acropodite process weakly sclerotized and covering the apical part of the solenomere, in ectal view and also is irregular.

\section{Female}

Unknown.

\section{Distribution}

The species is known only from the type locality.
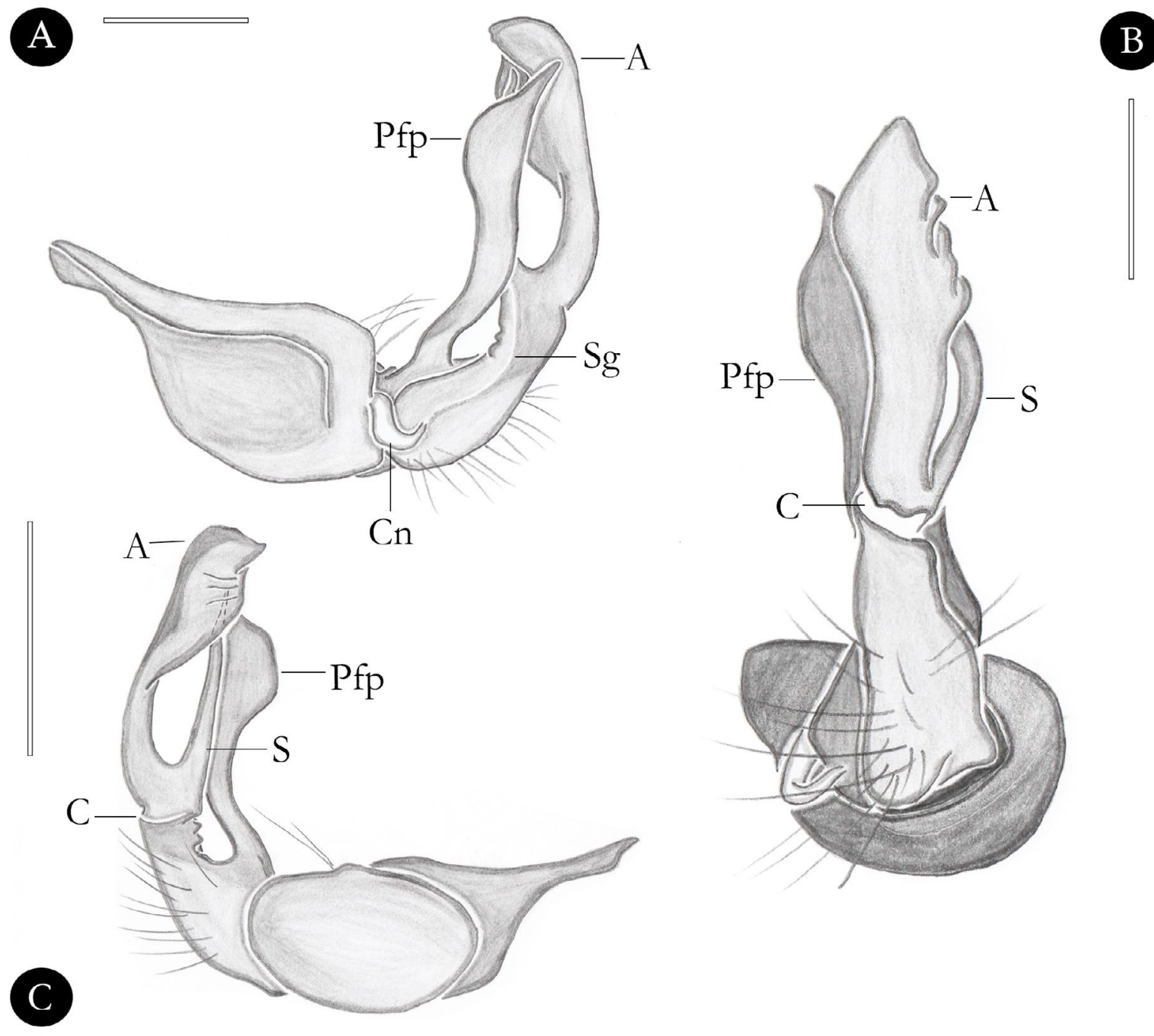

Fig. 3. Atlantodesmus sierwaldae sp. nov., holotype, $\widehat{\partial}$ (IBSP 180), schematic drawings of the gonopods. A. Mesal view. B. Ventral view. C. Ectal view. Scale bars: A-B $=250 \mu \mathrm{m} ; \mathrm{C}=500 \mu \mathrm{m}$. 


\section{Phylogenetic relationships}

The cladistic analysis returned two equally most parsimonious trees under value of the constant $k=3$, which showed the highest number of nodes shared (strict consensus presented in Fig. 1; and the two trees in Appendix 2), with the genus Atlantodesmus recovered as a monophyletic group, as suggested by Bouzan et al. (2017). The clade is supported by two synapomorphies and one homoplastic transformation: absence of ventral projection on the sternite just after the gonopods (char. $9[0]$ ), folds on dorsal edge of the prefemoral region (char. 18 [1]) and presence of a cingulum (char. 21, a presence shared with Arthrosolaenomeris pantalanensis). Despite forming a monophyletic group, the relationships of the species within the genus still remain unclear. Based on the topology, the species Atlantodesmus teresa was the first to diverge, and the latter group (A. eimeri + (A. itapurensis + A. sierwaldae $)+($ A. pickeli $+A$. pintoi $))$ was recovered as a trichotomy. In the strict consensus, the trichotomy is supported by two synapomorphies and one homoplastic transformation: absence of ventral projection on the fourth sternite (char. 5 [0]), paranota dorsally curved (char. 11 [2]) and a serrated prefemoral process (char. 19 [1], although reversed to the smooth aspect in A. sierwaldae). In the two trees obtained, the trichotomy was resolved with the grouping $(A$. eimeri $+($ A. pickeli + A. pintoi)) supported by a reduced cingulum (char 22 [0]) (Appendix 2, A), and with the grouping (A. eimeri $+($ A. itapurensis + A. sierwaldae) $)$ by a serrated lateral projection on the seventh sternite (Appendix 2, B).
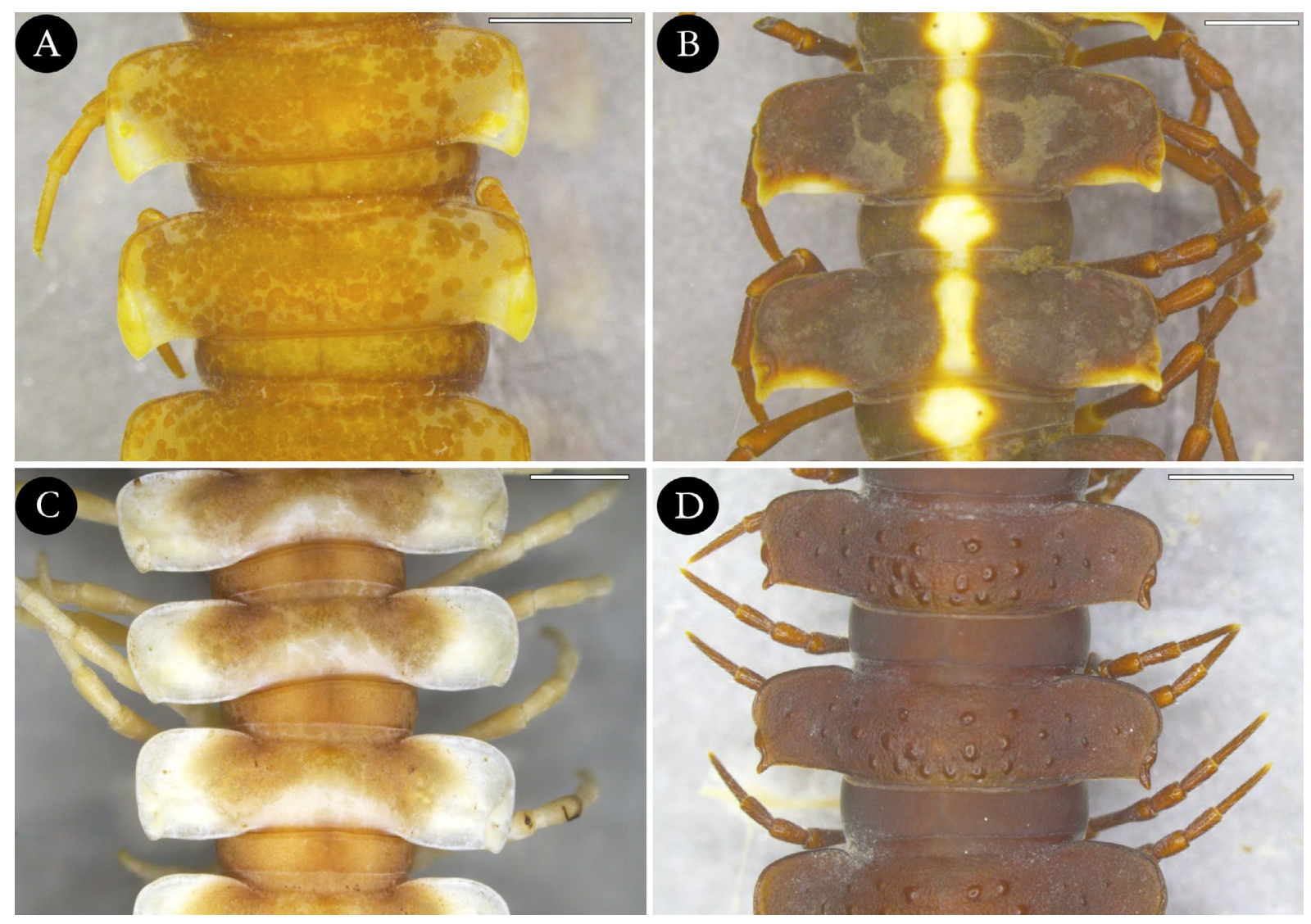

Fig. 4. Details of the tergites in the genus Atlantodesmus Hoffman, 2000. A. A. pickeli (Schubart, 1946). B. A. pintoi (Schubart, 1946). C. A. sierwaldae sp. nov. D. A. eimeri (Attems, 1898). Scale bars $=2 \mathrm{~mm}$. 


\section{Discussion}

As suggested by Hoffman (2000), the genus Atlantodesmus is possibly related to Leiodesmus Silvestri, 1897, and the presence of a well-defined cingulum on the telopodite (specified for the junior synonym Iemanja) would indicate a possible relationship with the genus Arthrosolaenomeris. However, based on our topology, neither genus was recovered close to Atlantodesmus. Although we found that the
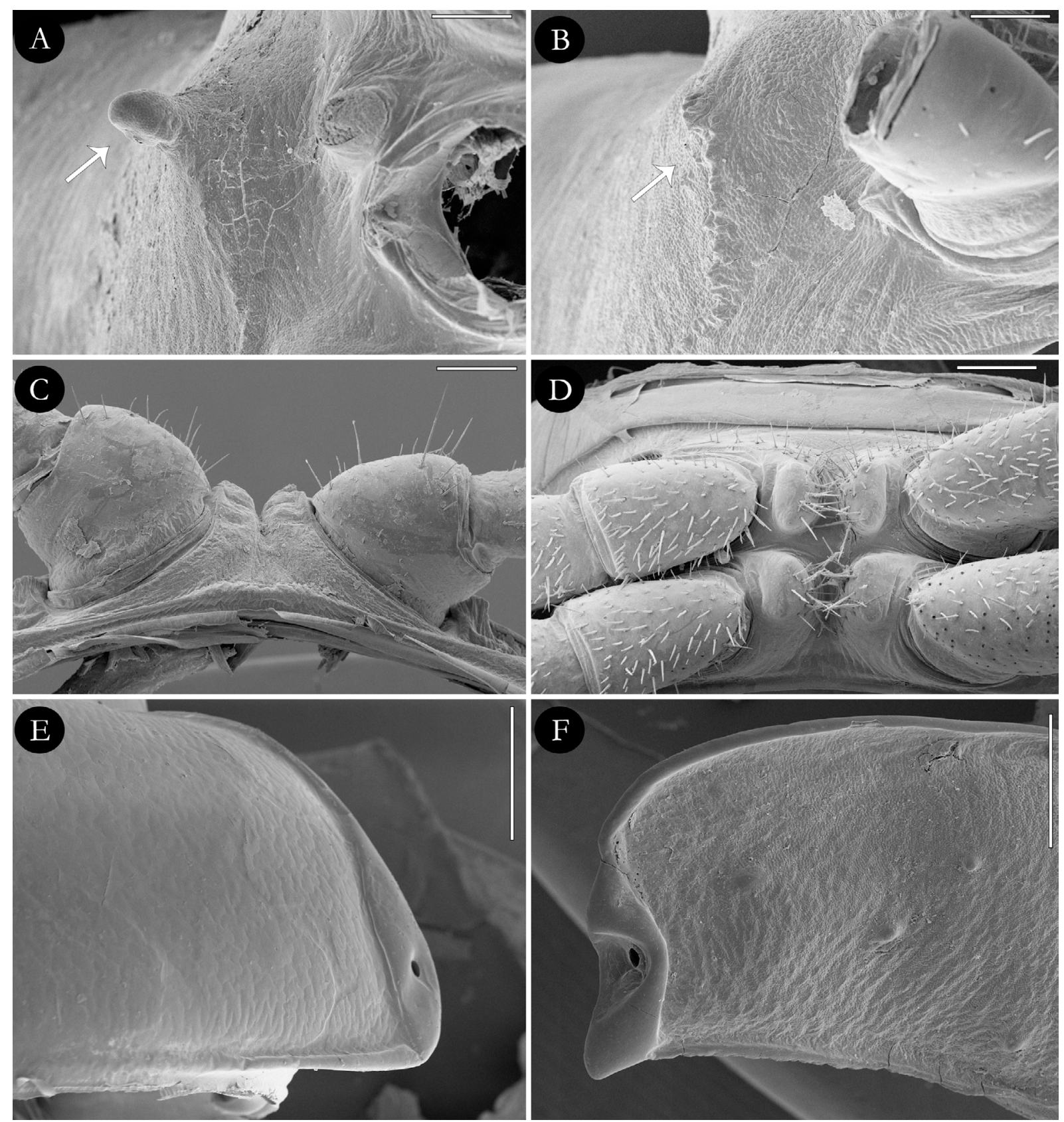

Fig. 5. A-B. Lateral projection on the seventh sternite. A. Smooth in Atlantodesmus eimeri (Attems, 1898). B. Serrated in A. pintoi (Schubart, 1946). C. Ventral projection on the fourth sternite in A. teresa (Hoffman, 2000). D. Ventral projection on the fifth sternite in Arthrosolaenomeris pantalanensis Schubart, 1943. E-F. Shape of the posterior edge of the paranota. E. Rounded in A. pantalanensis. F. Acuminate in Atlantodesmus eimeri (Attems, 1898). Scale bars: A-B $=250 \mu \mathrm{m} ; \mathrm{C}-\mathrm{F}=500 \mu \mathrm{m}$. 
genus Atlantodesmus is a well-supported clade, no inference concerning its tribal position was possible.

The phylogenetic relationship of the genus allows first insights into its biogeographic origin. The clade A. itapurensis + A. sierwaldae occurs mainly in areas containing the biome Cerrado, while the other taxa are distributed exclusively in the Atlantic rain forest. Concerning the cingulum, our results corroborate the suggestion made by Hoffman (2000), in which the presence of the structure is merely a recurrent homoplasy in different groups within the family. Importantly, phylogenetic relationships of the Chelodesmidae still require more investigation to achieve a better understanding of the morphological characters (Pena-Barbosa et al. 2013), as well as the delineation of its generic and tribal limits. This work presents important results about the evolution of the characters for Atlantodesmus, corroborating hypotheses from previous taxonomic treatments (Hoffman 2000; Bouzan et al. 2017).

\section{Acknowledgements}

We are grateful to Ricardo Pinto da Rocha and Mauro Cardoso Júnior (MZSP) and Amazonas Chagas-Jr (UFMT) for their hospitality during the visits, Beatriz Mauricio for helping with the SEM images in the Laboratório de Biologia Celular of the Instituto Butantan, and to R. Bassini Silva (IBSP) for his
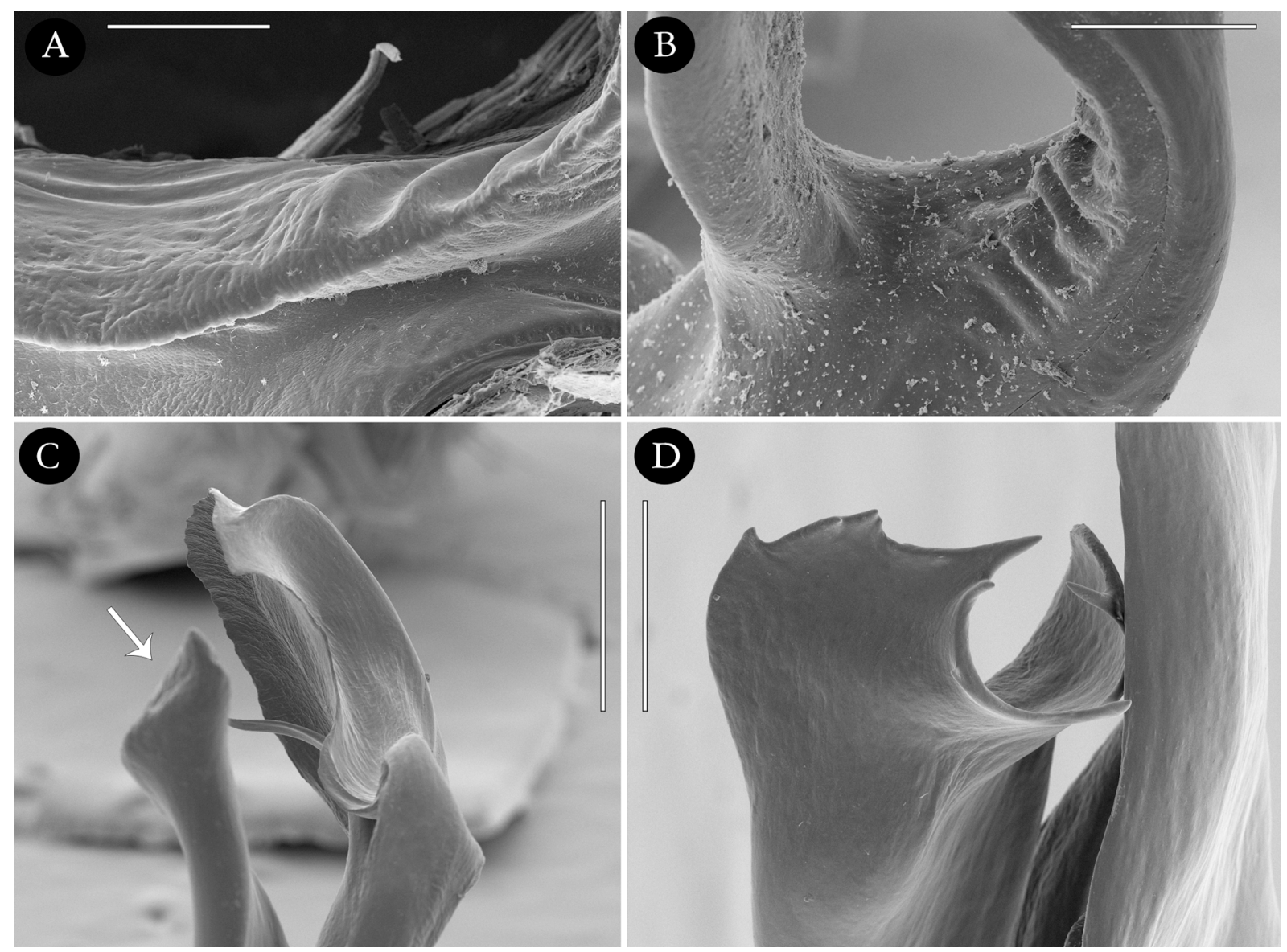

Fig. 6. A. Folds on the gonopod aperture in Atlantodesmus pintoi (Schubart, 1946). B. Folds on dorsal edge of the prefemoral region in A. pintoi. C. Smooth-edged prefemoral process in A. itapurensis (Schubart, 1943). D. Serrated prefemoral process in A. teresa (Hoffman, 2000). Scale bars: A-B $=2 \mathrm{~mm}$; $\mathrm{C}=500 \mu \mathrm{m} ; \mathrm{D}=200 \mu \mathrm{m}$. 
suggestions. Thanks to the Willi Hennig Society for allowing the use of the software TNT, and to J.P.P. Pena-Barbosa for making available his unpublished PhD thesis (2015): "Phylogenetic Framework for the Tribes of the Subfamily Chelodesminae Hoffman, 1980, Based on Morphological Characters (Diplopoda, Polydesmida, Chelodesmidae)". A special thanks to Derek Hennen (Virginia Tech) for all suggestions and for critical readings of the English, and to Ross Thomas for the second review. Thanks to the reviewers for all the suggestions. This study was financially supported by CNPq (130092/2018-5) grant to RSB and grant 2018/00103-8 from the São Paulo Research Foundation (FAPESP). LFMI was supported by grant 2016/24248-0 from FAPESP. ADB was supported by the grant CNPq (301776/20040 ). This study was financed in part by the Coordenação de Aperfeiçoamento de Pessoal de Nível Superior - Brasil (CAPES - Finance Code 001).

\section{References}

Attems C.G. 1898. System der Polydesmiden. I. Theil. Denkschriften der Kaiserlichen Akademie der Wissenschaften zu Wien, Mathematisch-Naturwissenschaftliche Klasse 67: 221-482.

Bouzan R.S., Pena-Barbosa J.P.P. \& Brescovit A.D. 2017. Taxonomic review of the genus Atlantodesmus Hoffman, 2000 (Polydesmida: Chelodesmidae). Zootaxa 4236: 269-290.

https://doi.org/10.11646/zootaxa.4236.2.3

Bouzan R.S., Iniesta L.F.M., Souza C.A.R. \& Brescovit A.D. 2019. A new record after a century and description of the female of Plectrogonodesmus gounellei (Brölemann 1902) (Polydesmida: Chelodesmidae). Studies on Neotropical Fauna and Environment 54 (1): 61-68.

https://doi.org/10.1080/01650521.2018.1536018

Bremer K. 1994. Branch support and tree stability. Cladistics 10: 295-304.

https://doi.org/10.1111/j.1096-0031.1994.tb00179.x

Brölemann H. 1900. Dous myriapodos notáveis do Brazil, Notas Myriapodologicas. Boletim do Museu Paraense de História Natural e Ethnographia 3: 65-71.

Goloboff P.A. 1993. Estimating character weights during tree search. Cladistics 9: 83-91. https://doi.org/10.1111/j.1096-0031.1993.tb00209.x

Goloboff P.A. \& Farris J.S. 2001. Methods for quick consensus estimation. Cladistics 17: S26-S34. https://doi.org/10.1111/j.1096-0031.2001.tb00102.x

Goloboff P.A., Farris J.S., Källersjö M., Oxelman B., Ramírez M.J. \& Szumik C.A. 2003. Improvements to resampling measures of group support. Cladistics 19: 324-332.

https://doi.org/10.1111/j.1096-0031.2003.tb00376.x

Goloboff P.A., Carpenter J.M., Arias J.S. \& Esquivel D.R.M. 2008a. Weighting against homoplasy improves phylogenetic analysis of morphological data sets. Cladistics 24: 758-773.

https://doi.org/10.1111/j.1096-0031.2008.00209.x

Goloboff P.A., Farris S. \& Nixon K. 2008b. TNT, a free program for phylogenetic analysis. Cladistics 24 (5): 774-786. https://doi.org/10.1111/j.1096-0031.2008.00217.x

Goloboff P.A. \& Catalano S.A. 2016. TNT version 1.5, including a full implementation of phylogenetic morphometrics. Cladistics 32: 221-238. https://doi.org/10.1111/cla.12160

Goloboff P.A., Torres A. \& Arias J.S. 2017. Weighted parsimony outperforms other methods of phylogenetic inference under models appropriate for morphology. Cladistics 34: 407-437.

https://doi.org/10.1111/cla.12205

Hoffman R.L. 1980. Classification of the Diplopoda. Múseum d'histoire naturelle, Genève. 
Hoffman R.L. 2000. Two new genera of chelodesmid millipeds from southeastern Brazil (Polydesmida: Chelodesmidae). Myriapodologica 6: 101-113.

Koch M. 2015. General morphology. In: Minelli A. (ed.) Treatise on Zoology - Anatomy, Taxonomy, Biology. The Myriapoda. Vol. 2. Leiden \& Boston, Brill. https://doi.org/10.1163/9789004188273_003

Nixon K.C. 2004. ASADO version 1.5 Beta. Published by the author. Ithaca, New York, USA.

Pena-Barbosa J.P.P., Sierwald P. \& Brescovit A.D. 2013. On the largest chelodesmid millipedes: taxonomic review and cladistic analysis of the genus Odontopeltis Pocock, 1894 (Diplopoda; Polydesmida; Chelodesmidae). Zoological Journal of the Linnean Society 169: 737-764.

https://doi.org/10.1111/zoj.12086

Rieppel O. \& Kearney M. 2002. Similarity. Biological Journal of the Linnean Society 75: 59-82. https://doi.org/10.1046/j.1095-8312.2002.00006.x

Sereno P.C. 2007. Logical basis for morphological characters in phylogenetics. Cladistics 23: 565-587. https://doi.org/10.1111/j.1096-0031.2007.00161.x

Strong E.E. \& Lipscomb D. 1999. Character coding and inapplicable data. Cladistics 15: 363-371. https://doi.org/10.1111/j.1096-0031.1999.tb00272.x

Manuscript received: 22 April 2019

Manuscript accepted: 12 June 2019

Published on: 19 July 2019

Topic editor: Rudy Jocqué

Desk editor: Pepe Fernández

Printed versions of all papers are also deposited in the libraries of the institutes that are members of the EJT consortium: Muséum national d'Histoire naturelle, Paris, France; Meise Botanic Garden, Belgium; Royal Museum for Central Africa, Tervuren, Belgium; Royal Belgian Institute of Natural Sciences, Brussels, Belgium; Natural History Museum of Denmark, Copenhagen, Denmark; Naturalis Biodiversity Center, Leiden, the Netherlands; Museo Nacional de Ciencias Naturales-CSIC, Madrid, Spain; Real Jardín Botánico de Madrid CSIC, Spain; Zoological Research Museum Alexander Koenig, Bonn, Germany; National Museum, Prague, Czech Republic. 


\section{Appendix 1}

List of terminal taxa scored for the cladistic analysis.

\section{Outgroup}

Strongylomorphini

Brasilodesmus paulistus paulistus (Brölemann, 1902)

BRAZIL • 1 đ̃; São Paulo, Peruíbe, Estação Ecológica Juréia/Itatins; $24^{\circ} 16^{\prime} 38^{\prime \prime}$ S, 4700'44" W; 5 Mar. 1994; A. Eterovic coll.; IBSP $1130 \bullet 1$ o; same collection data as for preceding; Dec. 1998; A.D. Brescovit et al. coll.; IBSP 981.

Macrocoxodesmus marcusi Schubart, 1947

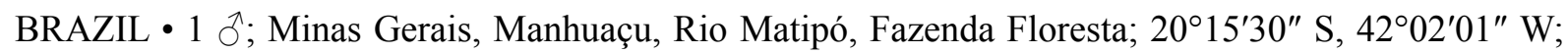
Dec. 1919; R. Fonseca coll.; MZUSP.

\section{Arthrosolaenomeridini}

Arthrosolaenomeris pantanalensis Schubart, 1943

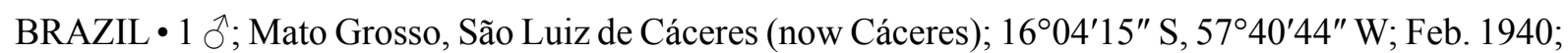
Passarelli coll.; MZUSP 1085 • 1 q; Porto Estrela, E.E. Serra das Araras; $15^{\circ} 19^{\prime} 28^{\prime \prime}$ S, 57 $7^{\circ} 13^{\prime} 39^{\prime \prime}$ W; 12 Nov. 2017; T.F. Conceição coll.; CZUFMT MYR 847.

\section{Without tribal designation}

Plectrogonodesmus gounellei (Brölemann, 1903)

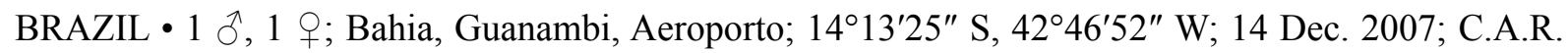
Souza et al. coll.; IBSP 3281.

\section{Leiodesmus sp.}

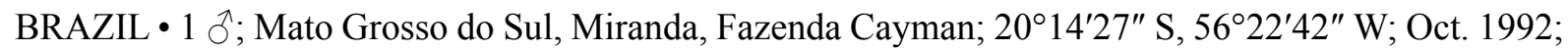
A. Eterovic coll.; IBSP1080.

\section{Ingroup}

Atlantodesmus eimeri (Attems, 1898)

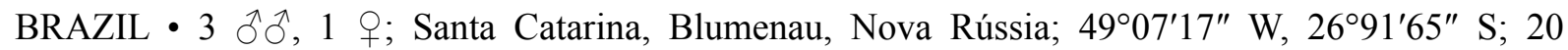
Feb. 2013; R.P. Indicatti and B. Gambaré coll.; IBSP 4367 • 1 \%; Paulo Lopes, Parque Estadual da Serra do Tabuleiro; 48 $80^{\prime} 35^{\prime \prime}$ W, 27 92'22" S; 10-20 Jan. 2003; Equipe Biota coll.; IBSP 2317.

Atlantodesmus itapurensis (Schubart, 1943)

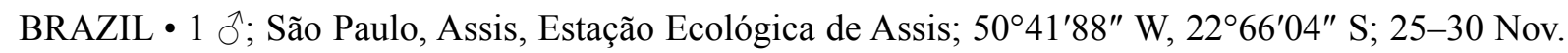
2002; Equipe Biota coll.; IBSP 2976 • 1 क ; same collection data; IBSP 2981. 


\section{Atlantodesmus pickeli (Schubart, 1946)}

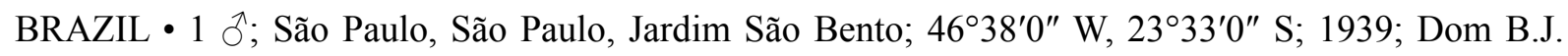
Pickel coll.; IBSP 29 • 1 \%; same collection data; IBSP 4433.

\section{Atlantodesmus pintoi (Schubart, 1946)}

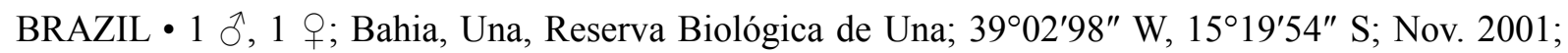
A.D. Brescovit coll.; IBSP 1001.

\section{Atlantodesmus teresa (Hoffman, 2000)}

BRAZIL • 1 + ; Espírito Santo, Linhares, Reserva Natural Vale do Rio Doce; 4006'37" W, 19¹3'74" S; 09-15 Jan. 2012; J.P.P. Pena-Barbosa et al. coll.; IBSP 4106 • 1 ơ; São Mateus Reserva Florestal do Vale do Rio Doce; 3985'67" W, 1871'91" S; 05-12 Jan. 1998; A.D. Brescovit coll.; IBSP 565.

\section{Atlantodesmus sierwaldae sp. nov.}

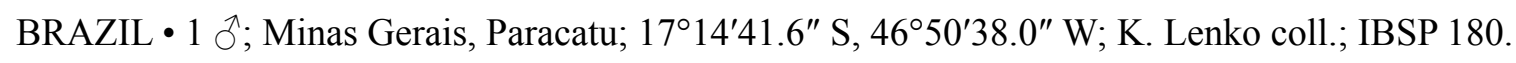




\section{Appendix 2}

The two most parsimonious trees (A and B) obtained in the cladistic analysis under implied weighting $(\mathrm{k}=3)$. Black circles correspond to unique transformations, and white circles correspond to homoplastic transformations. Only unambiguous changes are shown.

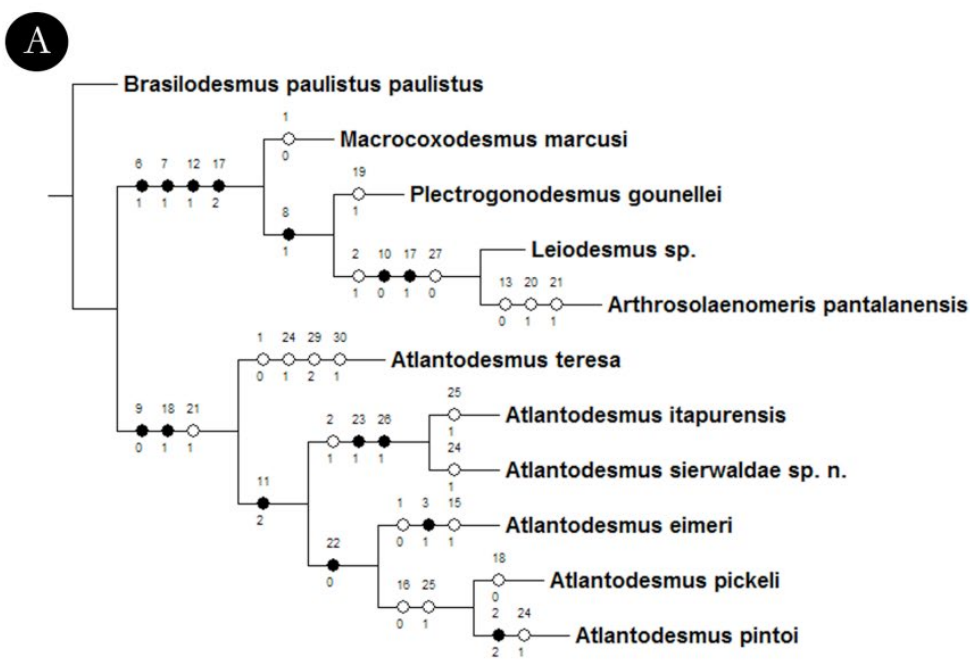

\section{B}

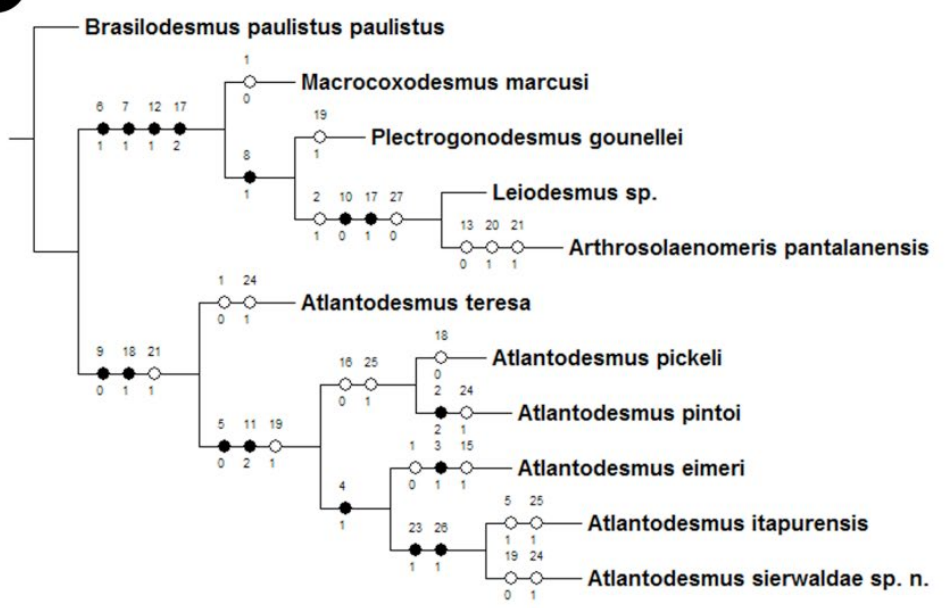

